\title{
WILLINGNESS TO PAY TEH HERBAL TAKOKAK MASA PANDEMI COVID-19 DI KOTA KEDIRI
}

\author{
Heru Setiyadi $^{1) *}$, Nunuk Helilusiatiningsih ${ }^{2)}$ \\ 1)*,2) Universitas Islam Kadiri \\ e-mail: herusetiyadi@uniska-kediri.ac.id ${ }^{1)^{*}}$, nunukhelilusi@gmail.com ${ }^{2)}$
}

\begin{abstract}
ABSTRAK
Konsumen mulai beralih menggunakan produk herbal yang terbukti mempunyai khasiat untuk tubuh bagi yang mengonsumsinya, termasuk minuman herbal. Salah satu jenis minuman herbal dengan keunggulan manfaat kesehatan adalah Teh Herbal Takokak yang berasal dari pengolahan buah takokak. Pada masa pandemi Covid- 19 seperti saat ini, tentunya teh herbal takokak bisa menjadi alternatif konsumen dalam mengoonsumsi minuman dengan orientasi kesehatan karena bisa meningkatkan imunitas. Tujuan penelitian ini adalah untuk mengetahui nilai willingness to pay (WTP) terhadap Teh Herbal Takokak serta mengetahui hubungan karakteristik responden dengan WTP Teh Herbal Takokak pada Masa Pandemi Covid-19 di Kota Kediri. Penelitian ini dilaksanakan pada September hingga Desember 2020 di Kota Kediri. Penelitian ini menggunakan populasi yaitu seluruh penduduk Kota Kediri dengan usia 30 tahun ke atas dengan sampel yang digunakan sebanyak 100 responden. Untuk mengetahui nilai WTP Teh Herbal Takokak pada Masa Pandemi Covid-19 di Kota Kediri menggunakan pendekatan Contingent Valuation Method (CVM) yang menanyakan langsung kepada responden mengenai nilai kesediaan membayar (harga) Teh Herbal Takokak di Kota Kediri. Sedangkan analisis hubungan karakteristik responden dengan kesediaan membayar WTP Teh Herbal Takokak pada Masa Pandemi Covid-19 di Kota Kediri menggunakan metode uji Chi-Square dengan SPSS. Dari penelitian yang telah dilakukan diperoleh hasil bahwa 1) nilai rataan WTP responden Teh Herbal Takokak sebesar Rp31.150 per 80 gram dan responden yang mempunyai WTP Teh Herbal Takokak sebesar 72 responden (72\%) dengan harga lebih dari sama dengan Rp30.000,00 per 80 gram; 2) karakteristik responden yang mempunyai hubungan siginifikan terhadap WTP Teh Herbal Takokak adalah status usia, tingkat pendidikan, tingkat pendapatan, status pekerjaan, dan status pengetahuan.
\end{abstract}

Kata Kunci: Covid-19, Teh Herbal Takokak, Willingness to Pay

\section{PENDAHULUAN}

Kesadaran konsumen tentang

kesehatan produk yang mereka konsumsi semakin meningkat sehingga memicu perusahaan untuk memproduksi dan menjual produk dengan konsep kesehatan (Lin et al, 2015). Hasil survei juga memperoleh realitas bahwa responden mempunyai tingkat 
ketertarikan yang tinggi dalam membeli produk herbal dengan alasan berasal dari bahan-bahan alami sebesar $84,1 \%$ serta tidak mempunyai efek samping sebesar 69,6\% (Fitrahnurlia, 2020). Konsumen mulai beralih menggunakan produk herbal yang terbukti mempunyai khasiat untuk tubuh bagi yang mengonsumsinya, termasuk minuman herbal (Nissa, 2013). Salah satu minuman herbal dengan keunggulan manfaat kesehatan adalah Teh Herbal Takokak yang berasal dari pengolahan buah takokak. Pada masa pandemi Covid- 19 seperti saat ini, tentunya teh herbal takokak bisa menjadi alternatif konsumen dalam mengkonsumsi minuman dengan orientasi kesehatan karena bisa meningkatkan imunitas. Konsumsi makanan bergizi serta sumber komponen bioaktif dengan aktivitas antiviral dan imunomodulator/ immune booster dapat meningkatkan daya tahan tubuh. Sumber komponen bioaktif tersebut meliputi beras merah/hitam, sorgum, ubi jalar, kacang-kacangan; berbagai sayur dan buah; produk hewani seperti olahan susu, telur dan madu; maupun minuman fungsional yang berasal dari herbal seperti Teh Herbal Takokak (Balai Besar Litbang Pascapanen Pertanian Kementan RI, 2020).

Sediaan herbal yang berpotensi dapat meningkatkan sistem imun antara lain adalah Terong Takokak. Seperti diketahui kandungan yang terdapat pada teh herbal takokak ini seperti antioksidan, anti bakteri pathogen, anti kanker, dan lain-lain. Produk baru seperti Teh Herbal Takokak perlu memperhatikan faktor harga dalam hal penetapan harga jual produk. Produk baru yang akan dipromosikan ke saluran pasar untuk pertama kalinya umumnya mengalami kendala dalam hal penetapan harga (Kotler, 2005). Lazimnya, penetapan harga produk masih berdasarkan sudut pandang produsen saja. Sehingga harga yang ditetapkan belum sesuai dengan harga pasar (market price). Sebagai upaya untuk memperoleh langsung berapa kesediaan membayar konsumen terhadap harga Teh Herbal Takokak, maka digunakan konsep Willingness To Pay (WTP) konsumen. Pemahaman yang mendalam mengenai konsumen akan meningkatkan pasar dan dapat mempengaruhi keputusan konsumen sehingga membeli apapun yang ditawarkan pemasar. Upaya untuk mengetahui kesediaan membayar konsumen merupakan salah satu langkah untuk memahami konsumen. Berdasarkan wawancara dengan pihak produsen, Teh Herbal Takokak, akan ditawarkan dengan harga Rp30.000,00 per 80 gram. Adapun tujuan dari penelitian ini adalah untuk mengetahui nilai willingness to pay terhadap teh herbal takokak serta mengetahui hubungan karakteristik responden dengan kesediaan membayar (Willingness to Pay) Teh Herbal Takokak pada Masa Pandemi Covid-19 di Kota Kediri.

\section{METODE PENELITIAN}

\section{Waktu dan Tempat Penelitian}

Penelitian ini dilaksanakan pada September hingga Desember 2020 di Kota Kediri. Penentuan Kota Kediri, Provinsi Jawa Timur ditentukan secara purposive (sengaja) berdasarkan pertimbangan yaitu merupakan salah satu tempat Teh Herbal Takokak akan dipasarkan. Penelitian ini 
menggunakan populasi yaitu seluruh penduduk Kota Kediri dengan usia 30 tahun ke atas karena usia tersebut mempunyai mindset lebih dewasa (matang) daripada usia di bawahnya (Sumarwan, 2015) dan tingkatan umur tersebut memiliki komitmen memikirkan kesehatan keluarganya, sehingga menjaga menjadi prioritas daripada mengobati (Herlambang dkk, 2011).

\section{Metode Penentuan Sampel}

Populasi merupakan objek/ subjek dengan jumlah dan sifat khas tertentu yang peneliti tetapkan dengan tujuan dipelajari serta disimpulkan (Sinambel, 2014). Penelitian ini menggunakan populasi yaitu penduduk di Kota Kediri dimana menurut data Badan Pusat Statistik Kota Kediri (2020) berjumlah 287.409 jiwa. Sementara sampel yang digunakan pada penelitian ini ditentukan menggunakan metode nonprobability sampling (sampel nonprobabilitas). Metode ini didasarkan pada pertimbangan peneliti, yaitu penetapan sampel secara sistematis atau sengaja (Dwiastuti, 2017) serta tidak memberikan peluang/ kesempatan yang sama bagi setap unsur atau anggota populasi untuk dipilih menjadi sampel (Tungga, 2014). Teknik non-probability sampling yang digunakan dalam penentuan sampel adalah convenience sampling yang mana responden siap terlibat pada suatu kajian atau penelitian/ tersedia untuk dikaji (Dwiastuti, 2017). Kriteria individu yang dijadikan sampel adalah penduduk Kota Kediri yang berusia lebih dari 30 tahun karena usia tersebut mempunyai mindset lebih dewasa (matang) daripada usia di bawahnya (Sumarwan,
2015) dan tingkatan umur tersebut memiliki komitmen memikirkan kesehatan keluarganya, sehingga menjaga menjadi prioritas daripada mengobati (Herlambang dkk, 2011). Adapun sampel yang digunakan sebanyak 100 responden yang dihitung menggunakan metode Slovin dengan taraf signifikan/kesalahan 10 persen (Sugiyono, 2001 dalam Bungin, 2005).

\section{Kategori Penelitian}

Kategori dalam penelitian ini merupakan penelitian deskriptif. Menurut Sumarwan (2004) bahwa penelitian deskriptif mempunyai tujuan untuk mendeskripsikan karakteristik atau fungsi pasar, diantaranya a) menggambarkan karakteristik konsumen, tenaga penjualan, organisasi, atau daerah pasar; b) memperkirakan persentase unit-unit populasi tertentu, menunjukkan perilaku tertentu; c) menentukan persepsi karakteristik produk; d) menentukan sejauh mana variabel pemasaran yang terkait; e) membuat prediksi spesifik. Penelitian deskriptif yang digunakan adalah penelitian menggunakan metode survei.

\section{Data dan Instrumentasi}

Penelitian ini menggunakan data primer dan sekunder. Data primer merupakan data yang berasal dari informasi yang didapatkan dari sumber pertama oleh peneliti atau pertama kali dicatat dan dikumpulkan oleh peneliti yang berkaitan dengan tujuan penelitian. Sementara data sekunder adalah data yang diperoleh dari publikasi pihak lain (Dwiastuti, 2017). Data primer dalam penelitian ini meliputi data jenis teh herbal yang dipasarkan di ritel 
modern Kota Kediri, data Produk Teh Herbal Takokak, data karakteristik responden, serta data hasil kuesioner mengenai nilai willingness to pay Teh Herbal Takokak. Sementara untuk data sekunder pada penelitian ini, yaitu data studi buku, data Jumlah Penduduk Menurut Kelompok Umur dan Jenis Kelamin Badan Pusat Statistik Kota Kediri.

\section{Metode Pengumpulan dan Pengolahan Data}

Data pada penelitian survei ini dikumpulkan menggunakan alat bantu atau instrumen yang disebut kuesioner. Menurut Dwiastuti (2017), kuesioner merupakan daftar pertanyaan yang berfungsi sebagi pedoman (guidance) dalam proses komunikasi antara petugas pengumpul data (enumerator) dengan narasumber (responden). Kuesioner dalam penelitian ini mempunyai tipe terbuka (open- ended questions), tertutup (close- ended questions), kombinasi terbuka-tertutup (close-open ended questions), berurutan (kontingensi).

Metode pengolahan dan analisis data untuk mengetahui nilai willingness to pay (harga) Teh Herbal Takokak pada Masa Pandemi Covid-19 di Kota Kediri menggunakan pendekatan Contingent Valuation Method (CVM) yang mengacu kepada Fauzi (2006) yang menanyakan langsung kepada responden mengenai nilai kesediaan membayar (harga) Teh Herbal Takokak di Kota Kediri. Sedangkan analisis hubungan karakteristik responden dengan kesediaan membayar (Willingness to Pay) Teh Herbal Takokak pada Masa Pandemi Covid-19 di Kota Kediri menggunakan metode uji Chi-Square dengan SPSS (Sulaiman, 2002).

\section{HASIL DAN PEMBAHASAN}

Karakteristik Responden

Hasil kuesioner menunjukkan bahwa sebaran responden menurut usia yaitu, sebanyak 68 responden berusia 26-45 tahun (kategori dewasa) dan 32 responden berusia 46-65 tahun (kategori lansia). Sebaran responden menurut usia ditunjukkan pada Gambar 1.

- Dewasa (26-45) — Lansia (46-65)

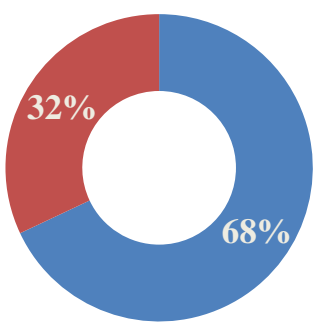

Gambar 1. Sebaran responden menurut Usia

Responden menurut tingkat pendidikan, sebanyak 80 responden mempunyai pendidikan tinggi (diploma dan universitas) dan sebanyak 20 responden berpendidikan menengah (Sekolah Menengah Pertama). Sebaran responden berdasarkan tingkat pendidikan ditunjukkan pada Gambar 2. 
- Pendidikan Tinggi (Diploma \& Universitas)

- Pendidikan Menengah (SMP)

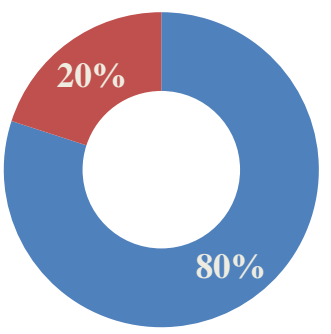

Gambar 2. Sebaran responde menurut tingkat pendidikan

Responden menurut tingkat pendapatan, yaitu sebanyak 78 responden mempunyai pendapatan lebih dari sama dengan Rp2.000.000,00 dan 22 responden pendapatan kurang dari sama dengan Rp2.000.000,00. Sebaran responden menurut tingkat pendapatan ditunjukkan pada Gambar 3.

- Pendapatan Tinggi (>= Rp2000000)

- Pendapatan Rendah (<= Rp2000000)

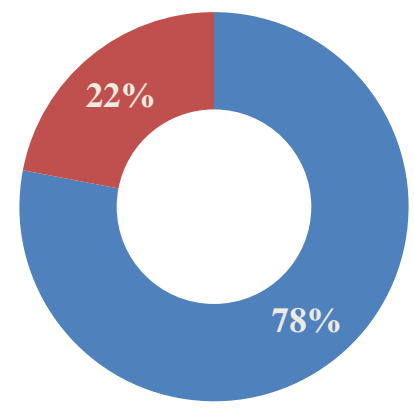

Gambar 3. Sebaran responden menurut tingkat pendapatan

Responden menurut jenis kelamin, yaitu jenis kelamin perempuan sebanyak 55 responden dan laki-laki sebanyak 45 responden. Sebaran responden menurut jenis kelamin ditunjukkan pada Gambar 4.

$$
\text { - Perempuan } \quad \text { Laki-Laki }
$$

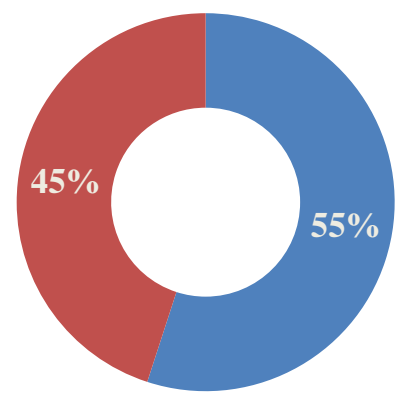

Gambar 4. Sebaran responden menurut jenis kelamin

Responden dengan status menikah responden sebanyak 76 responden dan belum menikah sebanyak 24 responden. Sebaran responden menurut status pernikahan ditunjukkan pada Gambar 5.

- Menikah $\quad$ Belum Menikah

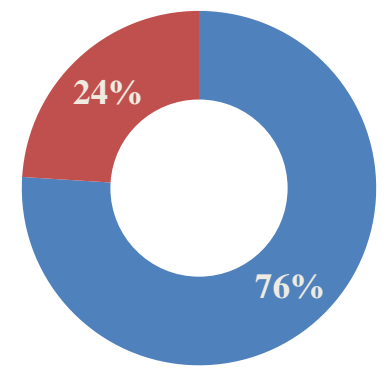

Gambar 5. Sebaran responden menurut status pernikahan

Responden menurut status pekerjaan buruh/ karyawan/ pegawai sebanyak 85 responden dan 15 responden non- buruh/ karyawan/ pegawai. Sebaran responden 
menurut status pekerjaan ditunjukkan pada Gambar 6.

\section{- Buruh/ Karyawan/ Pegawai \\ n Non-Buruh/ Karyawan/ Pegawai}

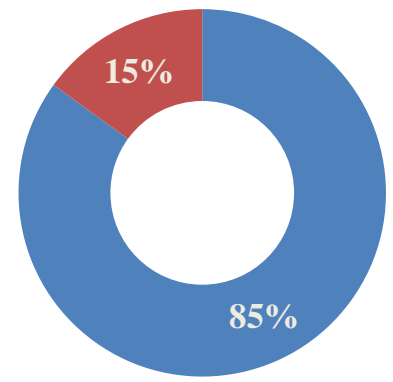

Gambar 6. Sebaran responden menurut status pekerjaan

Responden menurut pengetahuan, yaitu tahu minuman teh herbal sebanyak 76 responden dan sisanya 24 responden tidak tahu tentang minuman teh herbal. Sebaran responden menurut pengetahuan ditunjukkan pada Gambar 7.

$$
\square \text { Tahu Tidak Tahu }
$$

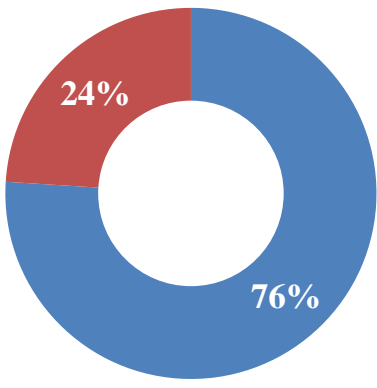

Gambar 7. Sebaran responden menurut pengetahuan

\section{Analisis Willingness to Pay Teh Herbal Takokak}

Kuesioner yang telah dibagikan kepada 100 responden penelitian di Kota Kediri, diperoleh hasil bahwa responden yang mempunyai kesediaan membayar (willingness to pay) Teh Herbal Takokak sebesar 72 responden (72\%) dengan harga lebih dari sama dengan Rp30.000,00 per 80 gram. Sedangkan sisanya sebanyak 28 responden tidak bersedia membayar Teh Herbal Takokak dengan harga Rp30.000,00 per 80 gram dan memilih harga lebih rendah. Adapun persentase kesediaan membayar (Willingness to Pay) Teh Herbal Takokak ditunjukkan pada Gambar 8.

$$
\square \text { Bersedia Bersedia }
$$

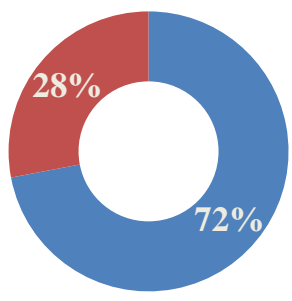

Gambar 8. Persentase kesediaan membayar (willingness to pay) teh herbal takokak

Analisis Willingness to Pay Teh Herbal Takokak pada Masa Pandemi Covid19 di Kota Kediri dilakukan dengan menggunakan pendekatan Contingent Valuation Method (CVM). Hasil yang diperoleh berdasarkan pendekatan tersebut sebagai berikut.

\section{Pasar Hipotesis}

Pasar hipotesis dalam analisis ini mempunyai isi tentang informasi mengenai munculnya Teh Herbal Takokak sebagai produk baru. Responden mendapat gambaran mengenai bahan dasar produk, kandungan yang terkandung dalam produk, 
beserta khasiat Teh Herbal Takokak. Tujuan dari pasar hipotesis pada penelitian ini adalah untuk mengonfirmasi langsung berapa nilai (harga) maksimum atas kesediaan membayar responden terhadap Teh Herbal Takokak pada Masa Pandemi Covid- 19 di Kota Kediri.

\section{Nilai Lelang}

Metode permainan lelang (Fauzi, 2006)) digunakan pada penelitian ini untuk mengetahui nilai Willingness to Pay Teh Herbal Takokak dimana responden diberi pertanyaan secara berulang-ulang mengenai kesediaan membayar maksimum. Nilai awal (starting point) yang digunakan adalah Rp30.000,00 per 80 gram. Dari hasil kuesioner didapat nilai maksimum sebesar Rp40.000.000 per 80 gram sedangkan nilai minimum sebesar Rp20.000,00 per 80 gram.

\section{Nilai Rataan WTP}

Nilai rataan Willingness to Pay (WTP) Teh Herbal Takokak pada Masa Pandemi di Kota Kediri sebesar Rp31.150,00 per 80 gram. Nilai (harga) yang bersedia dibayarkan responden ini lebih tinggi dibandingkan dengan harga yang ingin ditawarkan oleh Produsen Teh Herbal Takokak, yaitu Rp30.000,00 per 80 gram. Nilai rataan ini menandakan bahwa terdapat surplus konsumen karena nilai kesediaan membayar (WTP) yang diinginkan responden lebih tinggi dibandingkan nilai WTP rata-rata, yaitu sebesar Rp1.150,00.

\section{Agregat Data Total}

Nilai total Willingness to Pay (WTP) responden Teh Herbal Takokak dihitung berdasarkan data distribusi WTP responden. Hasil perhitungan diperoleh nilai total WTP responden sebesar Rp3.115.000,00.

\section{Hubungan Karakteristik Responden dengan Willingness to Pay Teh Herbal Takokak}

Karakteristik responden dalam penelitian ini terdiri dari status usia, tingkat pendidikan, tingkat pendapatan, jenis kelamin, status pernikahan, status pekerjaan, dan status pengetahuan. Untuk menganalisis hubungan karakteristik responden dalam penelitian ini dilakukan uji Chi Square memakai Statistical Package for the Social Sciences (SPSS). Adapun hasil Uji Chi Square hubungan karakteristik responden dengan willingness to pay Teh Herbal Takokak ditunjukkan pada Tabel 1 .

Tabel 1. Hasil Uji Chi Square Hubungan Karakteristik Responden dengan Willingness to Pay Teh Herbal Takokak

\begin{tabular}{lccc}
\hline \multicolumn{1}{c}{ Variabel } & Vhi Square Test & \\
\cline { 2 - 3 } & $\begin{array}{c}\text { Asymp. } \\
\text { Sig (2- } \\
\text { sided) }\end{array}$ & Korelasi \\
\hline $\begin{array}{l}\text { Status Usia * } \\
\text { Kesediaan } \\
\text { Membayar }\end{array}$ & 4,534 & 0,033 & Signifikan \\
\hline $\begin{array}{l}\text { Tingkat } \\
\text { Pendidikan * }\end{array}$ & 43,902 & 0,000 & Signifikan \\
$\begin{array}{l}\text { Kesediaan } \\
\text { Membayar }\end{array}$ & & & \\
\hline $\begin{array}{l}\text { Tingkat } \\
\text { Pendapatan * } \\
\text { Kesediaan }\end{array}$ & 68,021 & 0,000 & Signifikan \\
Membayar & & & \\
\hline $\begin{array}{l}\text { Jenis } \\
\text { Kelamin * }\end{array}$ & 0,884 & 0,347 & Signifikan \\
$\begin{array}{l}\text { Kesediaan } \\
\text { Membayar }\end{array}$ & & & \\
\hline $\begin{array}{l}\text { Status } \\
\text { Pernikahan * } \\
\text { Kesediaan } \\
\text { Membayar }\end{array}$ & 0,165 & 0,684 & Signifikan \\
\hline $\begin{array}{l}\text { Status } \\
\text { Pekerjaan * } \\
\text { Kesediaan } \\
\text { Membayar }\end{array}$ & 20,732 & 0,000 & Signifikan \\
\hline $\begin{array}{l}\text { Status } \\
\text { Pengetahuan } \\
* \text { Kesediaan } \\
\text { Membayar }\end{array}$ & 20,964 & 0,000 & Siginifikan \\
\hline
\end{tabular}


Sumber: Data Primer, diolah (2020)

Responden yang bersedia membayar Teh Herbal Takokak mempunyai usia 26-45 tahun (kategori dewasa) sebanyak 44 responden. Nilai Asymp. Sig (2-sided) menunjukkan angka 0,033 yang berarti lebih kecil dari taraf nyata yang digunakan $(0,033<0,05)$ menunjukkan bahwa terdapat hubungan karakteristik usia dengan kesediaan membayar Teh Herbal Takokak. Usia golongan dewasa memiliki banyak informasi mengenai sebuah produk yang ingin dikonsumsinnya (Nissa, 2013). Usia tersebut juga mempunyai komitmen dan perhatian terhadap kesehatan (Herlambang, dkk, 2011).

Responden yang bersedia membayar Teh Herbal Takokak mempunyai pendidikan tinggi (Diploma dan Sarjana) sebanyak 70 responden. Nilai Asymp. Sig (2-sided) menunjukkan angka 0,000 yang berarti lebih kecil dari taraf nyata yang digunakan $(0,000<0,05)$ menunjukkan bahwa terdapat hubungan tingkat pendidikan dengan kesediaan membayar Teh Herbal Takokak. Tingginya tingkat pendidikan seseorang berbanding lurus dengan pemahaman kesehatan, lingkungan, dan diversifikasi pangan yang dikonsumsi sehingga produk baru mudah diterima (Suwanda, 2012).

Responden yang bersedia membayar Teh Herbal Takokak mempunyai tingkat pendapatan tinggi sebanyak 72 responden. Nilai Asymp. Sig (2-sided) menunjukkan angka 0,000 yang berarti lebih kecil dari taraf nyata yang digunakan $(0,000<0,05)$ menunjukkan bahwa terdapat hubungan tingkat pendapatan dengan kesediaan membayar Teh Herbal Takokak. Pendapatan responden dalam penelitian ini yang berkategori tinggi menyebabkan munculnya kesadaran (awareness) terhadap kesehatan (Suwanda, 2012).
Responden yang bersedia membayar Teh Herbal Takokak mempunyai jenis kelamin perempuan sebanyak 37 responden. Nilai Asymp. Sig (2-sided) menunjukkan angka 0,347 yang berarti lebih besar dari taraf nyata yang digunakan $(0,347>0,05)$ menunjukkan bahwa tidak terdapat hubungan karakteristik jenis kelamin dengan kesediaan membayar Teh Herbal Takokak. Dari hasil kuesioner, walaupun responden perempuan bersedia membayar Teh Herbal Takokak, namun juga mempunyai banyak pertimbangan dan membandingkan dengan Minuman Herbal lainnya seperti teh rosella dan wedang uwuh.

Responden yang bersedia membayar Teh Herbal Takokak merupakan responden yang menikah sebanyak 56 responden. Nilai Asymp. Sig (2-sided) menunjukkan angka 0,684 yang berarti lebih besar dari taraf nyata yang digunakan $(0,684>0,05)$ menunjukkan bahwa tidak terdapat hubungan status pernikahan dengan kesediaan membayar Teh Herbal Takokak. Responden yang menikah maupun belum menikah membutuhkan konsumsi minuman dengan khasiat kesehatan sehingga tidak membatasi segmen konsumen dengan status pernikahan.

Responden yang bersedia membayar Teh Herbal Takokak mempunyai status pekerjaan buruh/ karyawan/ pegawai sebanyak 69 responden. Nilai Asymp. Sig (2sided) menunjukkan angka 0,000 yang berarti lebih kecil dari taraf nyata yang digunakan $\quad(0,000<0,05) \quad$ menunjukkan bahwa terdapat hubungan status pekerjaan buruh/ karyawan/ pegawai dengan kesediaan membayar Teh Herbal Takokak. Responden yang mempunyai pekerjaan seperti buruh/ karyawan/ pegawai cenderung meminati teh herbal dengan manfaat (khasiat) bagi tubuh (Herlambang, dkk, 2011).

Responden yang bersedia membayar Teh Herbal Takokak merupakan responden 
yang mengetahui minuman teh herbal. Nilai Asymp. Sig (2-sided) menunjukkan angka 0,000 yang berarti lebih kecil dari taraf nyata yang digunakan $(0,000<0,05)$ menunjukkan bahwa terdapat hubungan status pengetahuan dengan kesediaan membayar Teh Herbal Takokak. Konsumen yang memiliki pengetahuan dan pengalamn yang cukup mengenai produk serta informasi pelabelan dapat membentuk/ menambah keyakinan konsumen (Ameriana, 2006).

\section{KESIMPULAN}

Berdasarkan hasil penelitian yang telah didapatkan, maka disimpulkan bahwa :

a) Responden yang mempunyai kesediaan membayar (Willingness to Pay) Teh Herbal Takokak sebesar 72 responden $(72 \%)$ dengan harga lebih dari sama dengan Rp30.000,00 per 80 gram dengan nilai rataan WTP sebesar Rp31.150 per 80 gram.

b) Karakteristik responden yang mempunyai hubungan siginifikan terhadap kesediaan membayar Teh Herbal Takokak adalah status usia, tingkat pendidikan, tingkat pendapatan, status pekerjaan, dan status pengetahuan.

\section{DAFTAR PUSTAKA}

Ameriana M. 2006. Kesediaan Konsumen Membayar Premium untuk Tomat Aman Residu Pestisida. Jurnal Hortikultura Balitbang Pertanian 16(2):165-174. Diakses 28 Desember 2020 dari http://hortikultura.litbang.pertanian.go. id/jurnal_pdf/162/Ameriana_tomat.pdf

Badan Pusat Statistik Kota Kediri. 2020. Jumlah Penduduk Menurut Kelompok Umur dan Jenis Kelamin di Kota Kediri 2019.
Balai Besar Litbang Pascapanen Pertanian Kementan RI, 2020. Buku Saku Bahan Pangan Potensial untuk Anti Virus dan Imun Booster. Diakses 28 Desember $2020 \quad$ dari https://www.agropustaka.id/wpcontent/uploads/2020/07/BukuSaku_Bahan-Pangan-Potensial-untukAnti-Virus-dan-Imun-Booster.pdf

Bungin, Burhan. 2005. "Metode Penelitian Kuantitatif”. Prenada Media. Jakarta

Dwiastuti, Rini. 2017. "Metode Penelitian Sosial Ekonomi Pertanian (Dilengkapi Pengenalan Metode Penelitian Kuantitatif, Kualitatif, dan Kombinasi Kuantitatif Kualitatif)". UB Press. Malang

Fauzi, A. 2006. Ekonomi Sumber Daya Alam dan Lingkungan Teori dan Aplikasi. Gramedia Pustaka Utama. Jakarta

Fitrahnurlia, Andi Magie. 2020. "The 2nd Industry Roundtable: Pharmaceutical Industry Perspective- Key Findings MarkPlus: Product and Usage Frequency".

Herlambang dkk. 2011. Kajian Perilaku Konsumen terhadap Strategi Pemasaran Teh Herbal di Kota Bogor. Diakses 28 Desember 2020 dari https://journal.ipb.ac.id/index.php/jurn almpi/article/view/3750

Kotler, P. 2005. Manajemen Pemasaran Edisi Kesebelas Jilid 1. PT Indeks Kelompok Gramedia. Jakarta

Lin YC, Lee YC, Wang YF. 2015. "Exploring the influence of tea 
beverage health claims on brand evaluation and purchase intention". The international Journal of organizational innovation 8(2): 88-99. Diakses 28 Desember 2020 dari https://www.ijoi-

online.org/attachments/article/46/FIAL $\%$ 20ISSUE\%20VOL $\% 208 \% 20$ NUM

$\% 202 \% 200 C T O B E R \% 202015$.pdf

Nissa, Fatimah Khoirun. 2013. "Analisis Proses Keputusan Pembelian Dan Kepuasan Konsumen Produk Teh Rosela 'Rozelt' (Studi Kasus Konsumen Teh Rosela 'Rozelt' di Sekitar Institut Pertanian Bogor, Dramaga). Skripsi. Departemen Agribisnis Fakultas Ekonomi dan Manajemen Institut Pertanian Bogor Bogor. (internet). (diakses 28 Desember 2020) dari https://repository.ipb.ac.id/handle/123 456789/63914

Sinambela, Lijan Polta. 2014. Metodologi Penelitian Kuantitatif. Graha Ilmu. Yogyakarta

Sulaiman, Wahid. 2002. Statistik NonParametrik- Contoh Kasus dan Pemecahannyadengan SPSS. Andi. Yogyakarta:

Sumarwan, Ujang. 2004. Perilaku Konsumen Teori dan Penerapannya dalam Pemasaran. PT Ghalia Indonesia. Bogor

Sumarwan, Ujang. 2015. Perilaku Konsumen Teori dan Penerapannya dalam Pemasaran. PT Ghalia Indonesia. Bogor
Suwanda. Aklima Dhiska. 2012. Analisis Kesediaan Membayar (Willingness To Pay) Beras Analog di Serambi Botani, Botani Square, Bogor. Skripsi. Departemen Agribisnis Fakultas Ekonomi dan Manajemen Institut Pertanian Bogor Bogor. Diakses 28 Desember 2020 dari http://repository.ipb.ac.id/handle/1234 56789/60693

Tungga, Ananta Wikrama et al. 2014. Metodologi Penelitian Bisnis. Graha Ilmu. Yogyakarta 